\title{
Biomass and carbohydrates of spotted knapweed and Idaho fescue after repeated grazing
}

\author{
BRET E. OLSON AND ROSEANN T. WALLANDER
}

Authors are associate professor and research associate, Department of Animal and Range Sciences, Montana State University, Bozeman, Mont. 59717.

\begin{abstract}
Spotted knapweed (Centaurea maculosa Lam.), an aggressive Eurasian forb, is replacing many native perennial grasses such as Idaho fescue (Festuca idahoensis Elmer.) on foothills of the Northern Rocky Mountains. We assessed biomass allocation, carbohydrate reserves (total nonstructural carbohydrate concentrations - TNC), and carbohydrate pools (TNC $\times$ biomass) as indicators of cumulative effects of 3 summers (1991-1993) of repeated sheep grazing on spotted knapweed and Idaho fescue. In early May 1994, we excavated 30 spotted knapweed and Idaho fescue plants previously exposed to repeated grazing and 30 ungrazed plants of each species. On grazed Idaho fescue plants, shoot $(P<0.02)$ and root $(\mathrm{P}<0.06)$ biomass were 38 and $27 \%$ less than on ungrazed plants. In contrast, shoot $(P=0.26)$ and root biomass $(P=0.85)$ of grazed and ungrazed spotted knapweed plants were similar. Although grazing resulted in some minor differences in total nonstructural carbohydrate concentrations and carbohydrate pools of shoots, total nonstructural carbohydrate concentrations and pools of crowns and roots were similar for grazed and ungrazed plants of each species. Thus, carbohydrate concentrations or pools were not sensitive indicators of the response of Idaho fescue or spotted knapweed to the cumulative effects of repeated grazing. In contrast, aboveground biomass could be used to indicate the response of Idaho fescue to repeated grazing. By reducing shoot and root biomass of Idaho fescue but not spotted knapweed, repeated grazing may reduce the ability of Idaho fescue to compete with spotted knapweed when both species are grazed.
\end{abstract}

Key Words: reserves, allocation, weed, sheep, Centaurea maculosa, Festuca idahoensis

Spotted knapweed (Centaurea maculosa Lam.), an aggressive introduced perennial forb, has replaced many native perennial grasses in the foothills of the Northern Rocky Mountain region (Tyser and Key 1988, Lacey et al. 1992). Herbicides, insects, pathogens, and fire either have not contained the spread of this noxious weed, or may not be cost-effective in some situations. Most herbivores rarely graze this plant, possibly because it contains cnicin, a bitter tasting compound (Watson and Renny 1974,

We thank S. Givens for assisting with the study, and P. Hook, J. Lacey, and R. Sheley for reviewing the manuscript. This study was supported by the Montana Department of Agriculture Noxious Weed Trust Fund Grant Number 94-54 and the Montana Agricultural Experiment Station. This is published with approval of the Director of the Montana Agricultural Experiment Station, Journal Series J-3055.

Manuscript accepted 16 Jul. 1996.
Kelsey and Locken 1987), although some livestock producers have observed sheep grazing the plant (Cox 1989). In a greenhouse study, a single defoliation did not affect spotted knapweed, whereas monthly defoliations reduced root and crown weights, and carbohydrate concentrations of roots, crowns, and stems (Kennett et al. 1992, Lacey et al. 1994). In 1991, we began a 3year field study to assess cumulative effects of repeated sheep grazing on spotted knapweed and associated perennial grasses (Olson et al. 1993).

Herbage production, height and number of stems, and other physical characteristics have been used as indicators of plant vigor (Cook and Stubbendieck 1986). Carbohydrate reserves have also been used to indicate a plant's ability to regrow following defoliation and their overall vigor (e.g. McIlvanie 1942, Buwai and Trlica 1977), although this approach towards grasses has been challenged (Caldwell et al. 1981, Richards and Caldwell 1985). Carbohydrate reserves have also been considered important indicators of the status of native and introduced forbs (e.g. Donart 1969, Brummer and Bouton 1992). Our objective was to assess the biomass and carbohydrate status of spotted knapweed and Idaho fescue after 3 summers of repeated grazing by sheep.

\section{Methods and Materials}

Our study site was $14 \mathrm{~km}$ south of Bozeman, Mont. $\left(111^{\circ} 4^{\prime}\right.$ $45^{\circ} 36^{\prime}$ ). Elevation is $1,570 \mathrm{~m}$. Soils are of the Typic Argiboroll class, Beaverton series. They are shallow to moderately deep, silty clay loams over sand and gravel on an alluvial fan. The 30year precipitation average for the nearest weather station (Bozeman, Mont.) was $487 \mathrm{~mm}$. Precipitation for 1991-1993 in Bozeman was $99 \%, 115 \%$, and $123 \%$ of the 30 -year average, respectively. The summer (June-August) of 1991 was drier and warmer than the 30-year average, whereas the summers of 1992 and especially 1993 were wetter and cooler than the long term average (Table 1).

In the summers of 1991-1993, three 0.1-ha pastures were grazed repeatedly by 5 yearling Targhee sheep each summer. Pastures were grazed for 5 to 7 days in mid-June, 2 to 6 days in mid-July, and 1 to 5 days in early September depending on the available forage. Our intent was to graze the pastures intensively when Idaho fescue was in summer dormancy to minimize the impact on this native grass. Utilization of permanently marked plants of spotted knapweed and Idaho fescue was usually high, ranging from 56 to $99 \%$ based on grazed plant frequency (Olson 
Table 1. Thirty-year averages and 1991-1993 mean temperatures and total precipitation for May through August, Bozeman, Mont.

\begin{tabular}{|c|c|c|c|c|c|c|c|c|}
\hline \multirow[b]{2}{*}{ Month } & \multirow[b]{2}{*}{$\begin{array}{l}\text { 30-year } \\
\text { average }\end{array}$} & \multicolumn{3}{|c|}{ Temperature } & \multirow[b]{2}{*}{$\begin{array}{l}\text { 30-year } \\
\text { average }\end{array}$} & \multicolumn{3}{|c|}{ Precipitation } \\
\hline & & 1991 & 1992 & 1993 & & 1991 & 1992 & 1993 \\
\hline & $\ldots$ & $\cdots$ & C) - & - & $-\cdots$ & $\cdots-1$ & mm) - - & $\ldots$ \\
\hline May & 10.8 & 10.0 & 13.5 & 13.5 & 81 & 134 & 70 & 84 \\
\hline Jun. & 15.6 & 15.0 & 16.8 & 14.2 & 73 & 48 & 140 & 108 \\
\hline Jul. & 19.6 & 20.6 & 16.9 & 14.7 & 34 & 13 & 43 & 125 \\
\hline Aug. & 18.8 & 21.4 & 17.9 & 16.0 & 38 & 12 & 23 & 73 \\
\hline
\end{tabular}

et al., unpublished data), and 43 to $86 \%$ based on volume removed (Table 2).

On 2 May 1994, 1 to 2 weeks after spring growth began, we established one 30-m diagonal transect within each pasture $[\mathrm{n}=3$ pastures (blocks)], and four 10-m transects parallel to, but outside, the pasture in ungrazed areas. Ten grazed and 10 ungrazed spotted knapweed and Idaho fescue plants were located systematically at intervals along these transects. These plants, including their entire root systems, were excavated with a narrow blade shovel. By shaking and then rinsing each plant several times over a screen in cold water, soil and intermingling roots were separated from the plant. These plants were separated into shoots, crowns, and roots, placed on ice in a cooler, and transported to the laboratory. Crown biomass of Idaho fescue plants included stem bases. Plant materials were dried for 48 hours at $60^{\circ} \mathrm{C}$, weighed, and ground to pass a $1-\mathrm{mm}$ screen. Total nonstructural carbohydrates concentrations were determined at Colorado State University (AOAC 1965).

We analyzed biomass, TNC concentrations, and carbohydrate pools (TNC concentrations $\times$ mass) of shoots, crowns, and roots
Table 2. Estimated percent canopy removed of spotted knapweed and Idaho fescue during mid-June, mid-July, and early September of 1991-1993. Means \pm 1 S.E.

\begin{tabular}{|c|c|c|c|c|c|c|}
\hline & \multicolumn{2}{|c|}{1991} & \multicolumn{2}{|c|}{1992} & \multicolumn{2}{|c|}{1993} \\
\hline & $\begin{array}{c}\text { Spotted } \\
\text { knapweed }\end{array}$ & $\begin{array}{l}\text { Idaho } \\
\text { fescue }\end{array}$ & $\begin{array}{c}\text { Spotted } \\
\text { knapweed }\end{array}$ & $\begin{array}{l}\text { Idaho } \\
\text { fescue }\end{array}$ & $\begin{array}{c}\text { Spotted } \\
\text { knapweed }\end{array}$ & $\begin{array}{l}\text { Idaho } \\
\text { fescue }\end{array}$ \\
\hline & & & & & & \\
\hline Jun. & $79 \pm 11$ & $79 \pm 6$ & $45 \pm 10$ & $73 \pm 4$ & $57 \pm 3$ & $57 \pm 7$ \\
\hline Jul. & $75 \pm 5$ & $61 \pm 2$ & $62 \pm 8$ & $72 \pm 2$ & $56 \pm 2$ & $64 \pm 4$ \\
\hline Sep. & $58 \pm 8$ & $86 \pm 3$ & $43 \pm 4$ & $77 \pm 3$ & $58 \pm 3$ & $60 \pm 2$ \\
\hline
\end{tabular}

with ANOVA as a randomized-complete-block design ( $\mathbf{n}=3$; GLM, SAS 1988). Main effects of treatment (grazed, ungrazed) and species (Idaho fescue, spotted knapweed), and the treatment by species interaction were tested with ANOVA. Residuals from ANOVA were normally distributed. P-values less than 0.15 are presented (Gill 1981). We present least square means and standard errors.

\section{Results}

Shoot and root biomass were less on grazed than ungrazed Idaho fescue plants, whereas shoot and root biomass of grazed and ungrazed spotted knapweed plants were similar (species $X$ treatment, shoot $P<0.02$, root $P<0.18$, Fig. 1). Grazing did not reduce crown biomass of either species. Crown and root biomass of Idaho fescue plants were greater than crown and root biomass of spotted knapweed plants $(\mathrm{P}<0.1, \mathrm{P}<0.001)$.

Based on biomass, root:shoot ratios of grazed spotted knap-
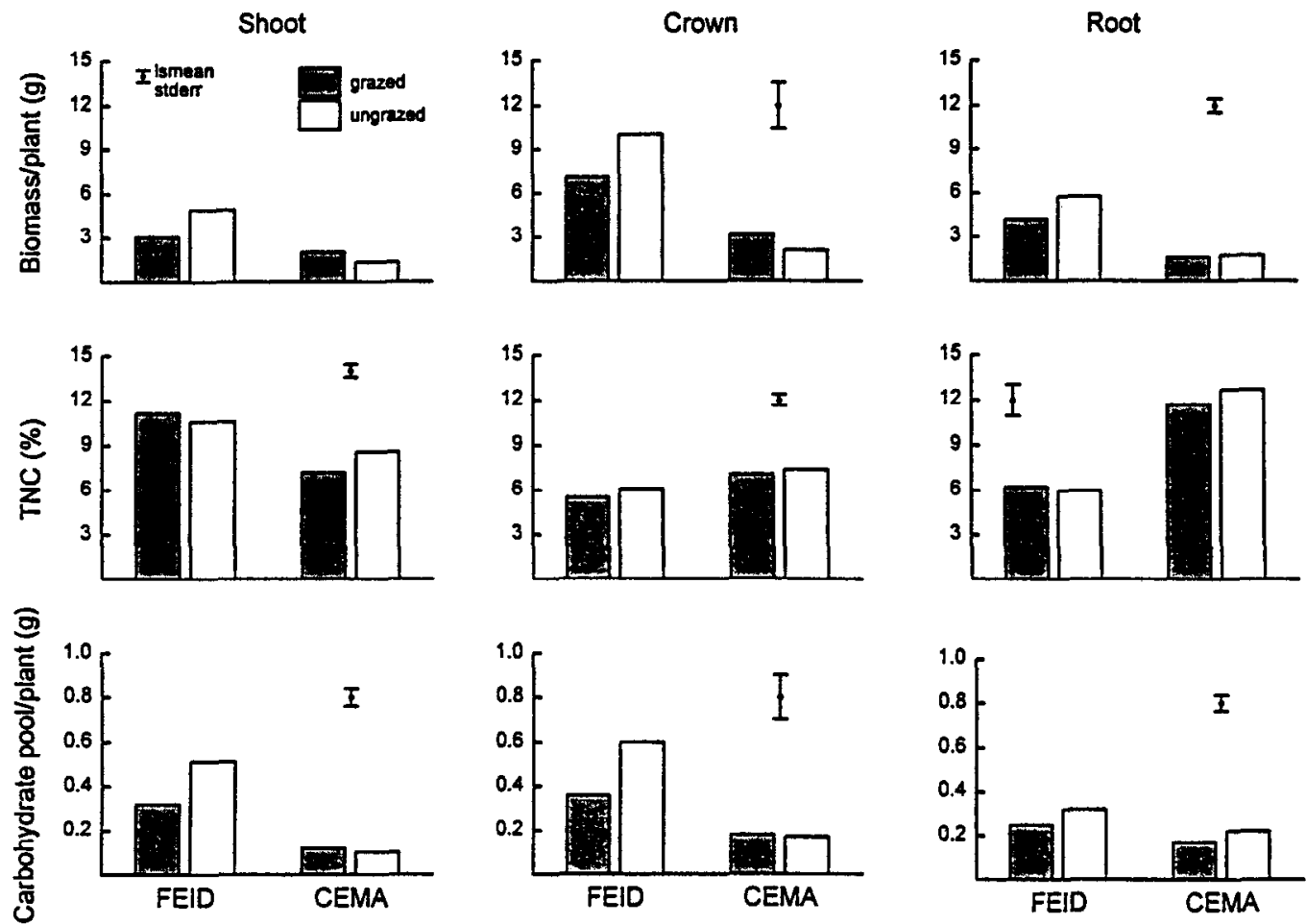

Fig. 1. Biomass, total nonstructural carbohydrate concentrations, and carbohydrate pools of shoots, crowns, and roots of Idaho fescue (FEID) and spotted knapweed (CEMA) after 3 summers (1991-1993) of repeated graxing. Plants were excavated 2-4 May 1994 (n $=3$ blocks). Least square means and standard errors are presented. 
weed plants averaged $0.9 \pm 0.1$ S.E., whereas ratios of ungrazed spotted knapweed plants averaged $1.5 \pm 0.4$. Root:shoot ratios of grazed Idaho fescue plants averaged $1.6 \pm 0.3$, whereas ratios of ungrazed Idaho fescue plants averaged $1.3 \pm 0.1$.

Total nonstructural carbohydrate concentrations were similar in shoots of grazed and ungrazed Idaho fescue plants, whereas they were higher in shoots of ungrazed than in grazed spotted knapweed plants (species $X$ treatment, $P<0.07$, Fig. 1). Grazing did not affect carbohydrate concentrations of crowns and roots of either species. Carbohydrate concentrations of crowns $(P<0.1)$ and roots $(P<0.001)$ of spotted knapweed plants were higher than those of Idaho fescue.

Shoot carbohydrate pools (TNC $\times$ biomass) of grazed Idaho fescue plants were less than shoot carbohydrate pools of ungrazed plants, whereas shoot carbohydrate pools of grazed and ungrazed spotted knapweed were similar (species $\times$ treatment, $P<0.03$, Fig. 1). Grazing did not affect crown and root carbohydrate pools of either species. Crown $(\mathrm{P}<0.02)$ and root $(\mathrm{P}<0.05)$ carbohydrate pools of Idaho fescue plants were greater than those pools of spotted knapweed plants, reflecting differences in biomass not carbohydrate concentrations.

\section{Discussion}

\section{Biomass}

Three years of repeated sheep grazing reduced shoot and root biomass of Idaho fescue, indicating that the ability of Idaho fescue to compete may have been compromised. Reductions in root growth, length, or biomass were measured in several short term studies (Crider 1955, Hodgkinson and Baas-Becking 1977 , Richards 1984, Brown 1985), whereas long term responses are measured less often (Cook et al. 1958). Effects of a single extreme defoliation of Idaho fescue that reduced herbage volume 85\% and eliminated flower stem production were still evident after 5 years (Mueggler 1975). Presumably, the lengthy recovery time of Idaho fescue in his study was related to concomitant reductions in root biomass following defoliation. In contrast, 3 years of repeated grazing did not reduce crown or root biomass of spotted knapweed. Shoot biomass was actually greater on grazed than ungrazed plants. Natural and simulated herbivory increases shoot and root biomass of another tap-rooted forb, scarlet gilia (Ipomopsis aggregata Pursh Spreng.; Paige and Whitham 1987). Changes in biomass of thick, woody roots of forbs may be less responsive to environmental perturbations, unlike fibrous roots of grasses which turnover rapidly (Sims and Singh 1978). Further, fine roots of grasses represent minimal investment and are readily decomposed, whereas taproots of forbs represent greater investment by the plant, and are not readily decomposed. Decomposition of roots of certain forbs such as spotted knapweed may be further slowed by presence of secondary compounds (Locken and Kelsey 1987).

Although shoot, crown, and root biomass of Idaho fescue were greater than counterparts of spotted knapweed, grazing reduced shoot and root biomass of Idaho fescue indicating a lower tolerance to repeated defoliation than spotted knapweed. Our intent was to intensively graze pastures primarily when the cool season Idaho fescue should have been dormant. However, Idaho fescue may have remained physiologically active and thereby more sensitive to defoliation during cool wet summers of 1992 and 1993. Reduced biomass of shoots, crowns, and roots of Idaho fescue after repeated defoliation may not be critical when plants are growing with other native species. However, it may be especially critical when competing with introduced species that avoid, or are more tolerant of grazing, or both (Briske 1990).

On an individual plant level, grazing negatively affected Idaho fescue but not spotted knapweed, although the response at the community level is less conclusive (Olson et al. 1997). Repeated sheep grazing altered the age distribution of spotted knapweed, resulting in fewer 1 to 3 year-old plants in the population. In contrast, basal areas of Idaho fescue plants from grazed and ungrazed areas were similar, although grazed plants had shorter leaves and flower stems than ungrazed plants (Olson et al. 1997). These nondestructive measures agree with reduced biomass of grazed Idaho fescue plants measured in this study.

Based on lower root:shoot ratios, grazed spotted knapweed plants allocated more biomass aboveground than ungrazed plants, possibly to increase reproductive effort (Paige and Whitham 1987). Similar root:shoot ratios of grazed and ungrazed Idaho fescue plants indicates Idaho fescue does not allocate additional resources to reproductive effort. Idaho fescue produces few, if any, flower stems when grazed heavily (Mueggler 1975). With plants maintaining a relatively constant root:shoot ratio, such as Idaho fescue, reduced aboveground biomass after repeated defoliation will reflect reduced belowground biomass (Cook et al. 1958).

\section{Carbohydrate Concentrations}

Similar total nonstructural carbohydrate concentrations of roots, crowns, and shoots of grazed and ungrazed Idaho fescue plants indicates this was not an appropriate measure of plant response to grazing 3 consecutive years. We sampled plants only once, early in the growing season when carbohydrate concentrations are usually lowest (Menke and Trlica 1981). We expected to detect the greatest differences at this time. However, warming soil and air temperatures 1 to 2 weeks before we excavated the plants could have maximized photosynthetic rates, restoring carbohydrate concentrations. Other bunchgrasses replenish carbohydrate pools within 1 to 3 days (Richards and Caldwell 1985), which is one reason to challenge using carbohydrate concentrations to predict response to grazing.

The higher nonstructural carbohydrate concentrations in ungrazed spotted knapweed shoots could reflect accumulation of photoassimilate in rosette leaves, whereas previously grazed plants may have allocated photoassimilate to depleted root and crown materials at the expense of shoot carbohydrate concentrations. In the rosette stage, Canada thistle (Cirsium arvense $\mathrm{L}$. Scop.) rapidly moves photoassimilate to roots even without defoliation (Tworkoski 1992). Allocation and storage patterns of nonstructural carbohydrates have been used to manage alfalfa (Medicago sativa; e.g. Brummer and Bouton 1992), although others have found taproot carbohydrate concentrations are not correlated with yields in the subsequent year or with winter survival of this species (Reynolds 1971, Boyce and Volonec 1992). Similarly, our results indicate carbohydrate concentrations of spotted knapweed are not correlated with growth or survival.

In our study, carbohydrate pools of Idaho fescue plants were reduced by grazing, but this reflected changes in biomass, not carbohydrate concentrations. Carbohydrate pools have been suggested as a more appropriate indicator of the amount of nonstructural carbohydrates mobilized or used to support various metabol- 
ic processes (Caldwell et al. 1981, Richards and Caldwell 1985), although neither changes in carbohydrate concentrations nor pools explain the differential response of bluebunch (Pseudoroegneria spicata [Pursh] A. Love) and crested wheatgrass (Agropyron desertorum Fischer ex Link, Schultes) to defoliation (Caldwell et al. 1981, Richards and Caldwell 1985). Other factors, including meristematic limitations, different storage compounds, residual leaf material, and changes in allocation or growth patterns, may better explain short and long-term responses of grasses and forbs to defoliation than carbohydrate status (Crider 1955, Richards 1984, Brummer and Bouton 1992).

\section{Conclusions}

Three years of repeated sheep grazing reduced shoot and root biomass of Idaho fescue, whereas shoot and root biomass of spotted knapweed were not reduced. Chronic reductions in aboveand belowground biomass would reduce the competitiveness of Idaho fescue. Carbohydrate concentrations or pools did not appear to be sensitive indicators of the response of Idaho fescue and spotted knapweed to cumulative effects of repeated grazing.

\section{Literature Cited}

Association of Official Agricultural Chemists. 1965. Official methods of analysis. 10th ed. Wash. D.C.

Boyce, P.J. and J.J. Volenec. 1992. Taproot carbohydrate concentrations and stress tolerance of contrasting alfalfa genotypes. Crop Sci. 32:757-761.

Briske, D.D. 1990. Developmental morphology and physiology of grasses, p. 85-108. In: R.K. Heitschmidt and J.W. Stuth (eds.) Grazing management: an ecological perspective. Timber Press, Portland, Ore.

Brown, R.F. 1985. The effect of severe defoliation on the subsequent growth and development of five rangeland pasture grasses of southwestern Queensland. Aust. J. Ecol. 10:335-343.

Brummer, E.C. and J.H. Bouton. 1992. Physiological traits associated with grazing-tolerant alfalfa. Agron. J. 84:138-143.

Buwai, M. and M.J. Trlica. 1977. Multiple defoliation effects on herbage yield, vigor, and total nonstructural carbohydrates of five range species. J. Range Manage. 30:164-171.

Caldwell, M.M., J.H. Richards, D.A. Johnson, R.S. Nowak, and R.S. Dzurec. 1981. Coping with herbivory: photosynthetic capacity and resource allocation in two semiarid Agropyron bunchgrasses. Oecologia 50:14-24.

Cook, C.W., L.A. Stoddart, and F.E. Kinsinger. 1958. Responses of crested wheatgrass to various clipping treatments. Ecol. Mono. 28:237-272.

Cook, C.W. and J. Stubbendieck. 1986. Range research: Basic problems and techniques. Soc. Range Manage. Denver, Colo.

Cox, J.W. 1989. Observations, experiments and suggestions for research on the sheep-spotted knapweed relationship, p. 79-82. In: P.K. Fay and J.R. Lacey (eds.), Proc. Knapweed Symposium. Montana State Univ., Bozeman, Mont.

Crider, F. 1955. Root growth stoppage resulting from defoliation of grass. USDA Tech. Bull. 1102.

Donart, G.B. 1969. Carbohydrate reserves of six mountain plants as related to growth. J. Range Manage. 22:411-415.

Gill, J.L. 1981. Evolution of statistical design and analysis of experiments. J. Dairy Sci. 64:1494-1519.

Hodgkinson, K.C. and H.G. Baas-Becking. 1977. Effect of defoliation on root growth of some arid zone perennial plants. Aust. J. Agr. Res. 29:31-42.
Kelsey, R.G., and L.J. Locken. 1987. Phytotoxic properties of cnicin, a sesquiterpene lactone from Centaurea maculosa (spotted knapweed). J. Chem. Fcol. 13:19-33.

Kennett, G.A., J.R. Lacey, C.A. Butt, K.M. Olson-Rutz, and M.R. Haferkamp. 1992. Effects of defoliation, shading and competition on spotted knapweed and bluebunch wheatgrass. J. Range Manage. 45:363-369.

Lacey, C.A., J.R. Lacey, P.K. Fay, J.M. Story, and D.L. Zamora. 1992. Controlling knapweed on Montana tangeland. Mont. State Univ. Ext. Ser. Circ. 311 , Bozeman, Mont.

Lacey, J.R., K.M. Olson-Rutz, M.R. Haferkamp, and G.A. Kennett. 1994. Effects of defoliation and competition on total nonstructural carbohydrates of spotted knapweed. J. Range Manage. 47:481-484.

Locken L.J. and R.G. Kelsey. 1987. Cnicin concentrations in Centaurea maculosa, spotted knapweed. Biochem. Syst. Ecol. 15:313-320.

McIlvanie, S.K. 1942. Carbohydrate and nitrogen trends in bluebunch wheatgrass (Agropyron spicatum) with special reference to grazing influences. Plant Phys. 17:540-557.

Menke, J.W. and M.J. Trlica. 1981. Carbohydrate reserve, phenology, and growth cycles of nine Colorado range species. J. Range Manage. 34:269-277.

Mueggler, W.F. 1975. Rate and pattern of vigor recovery in Idaho fescue and bluebunch wheatgrass. J. Range Manage. 28:198-204.

Olson, B.E., R.T. Wallander, and J.R. Lacey. 1993. Sheep grazing spotted knapweed, p. 17-18. In: Proc. Weed management: Facing the issues. Mont. Weed Control Assoc., Butte, Mont.

Olson, B.E., R.T. Wallander, and J.R. Lacey. 1997. Effects of sheep grazing on a spotted knapweed-infested Idaho fescue community. $\boldsymbol{J}$. Range Manage. 50:386-390.

Paige, K.N. and T.G. Whitham. 1987. Overcompensation in response to mammalian herbivory: the advantage of being eaten. Amer. Nat. 129:408-416.

Reynolds, J.H. 1971. Carbohydrate trends in alfalfa (Medicago sativa L.) roots under several forage harvest schedules. Crop Sci. 11:103-106.

Richards, J.H. 1984. Root growth responses to defoliation in two Agropyron bunchgrasses: field observations with an improved root periscope. Oecologia 64:21-25.

Richards, J.H. and M.M. Caldwell. 1985. Soluble carbohydrates, concurrent photosynthesis and efficiency in regrowth following defoliation: a field study with Agropyron species. J. Appl. Ecol. 22:907-920.

SAS. 1988. Statistical analysis system. SAS Institute Inc. Raleigh, N.C.

Sims, P.L. and J.S. Singh. 1978. The structure and function of ten western North American grasslands. III. Net primary production, turnover, and efficiencies of energy capture and water use. J. Ecol. 66:573-597.

Tworkoski, T. 1992. Developmental and environmental effects on assimilate partitioning in Canada thistle (Cirsium arvense). Weed Sci. 40:79-85.

Tyser, R.W. and C.H. Key. 1988. Spotted knapweed in natural area fescue grasslands: an ecological assessment. Northwest Sci. 62:981-987.

Watson, A.K. and A.J. Renny. 1974. The biology of Canadian weeds. Centaurea diffusa and C. maculosa. Can. J. Plant Sci. 54:687-701. 